\title{
Effects of oil and natural or synthetic vitamin E on ruminal and milk fatty acid profiles in cows receiving a high-starch diet
}

\author{
A. Zened, ${ }^{\star} \dagger \ddagger$ A. Troegeler-Meynadier, ${ }^{\star} \dagger \ddagger$ T. Najar,§ and F. Enjalbert ${ }^{\star}+\ddagger^{1}$ \\ *INRA, UMR1289 Tissus Animaux Nutrition Digestion Ecosystème et Métabolisme, F-31326 Castanet-Tolosan, France \\ †Université de Toulouse, INPT ENSAT, UMR1289 Tissus Animaux Nutrition Digestion Ecosystème et Métabolisme, F-31326 Castanet-Tolosan, \\ France \\ fUniversité de Toulouse, INPT ENVT, UMR1289 Tissus Animaux Nutrition Digestion Ecosystème et Métabolisme, F-31076 Toulouse, France \\ $\S$ Institut National Agronomique de Tunis, T-1082 Tunis, Tunisia
}

\section{ABSTRACT}

Among trans fatty acids, trans-10,cis-12 CLA has negative effects on cow milk fat production and can affect human health. In high-yielding dairy cows, a shift from the trans-11 to the trans-10 pathway of biohydrogenation $(\mathrm{BH})$ can occur in the rumen of cows receiving high-concentrate diets, especially when the diet is supplemented with unsaturated fat sources. In some but not all experiments, vitamin $\mathrm{E}$ has been shown to control this shift. To ascertain the effects of vitamin $\mathrm{E}$ on this shift of BH pathway, 2 studies were conducted. The first study explored in vitro the effects of addition of natural (RRR- $\alpha$-tocopherol acetate) and synthetic (DL- $\alpha$-tocopherol acetate) vitamin E. Compared with control and synthetic vitamin $\mathrm{E}$, the natural form resulted in a greater trans-10/trans-11 ratio; however, the effect was very low, suggesting that vitamin $\mathrm{E}$ was neither a limiting factor for rumen $\mathrm{BH}$ nor a modulator of the $\mathrm{BH}$ pathway. An in vivo study investigated the effect of natural vitamin E (RRR- $\alpha$-tocopherol) on this shift and subsequent milk fat depression. Six rumenfistulated lactating Holstein cows were assigned to a 2 $\times 2$ crossover design. Cows received $20-\mathrm{kg}$ DM of a control diet based on corn silage with $22 \%$ of wheat, and after 2 wk of adaptation, the diet was supplemented with $600 \mathrm{~g}$ of sunflower oil for 2 more weeks. During the last week of this 4-wk experimental period, cows were divided into 2 groups: an unsupplemented control group and a group receiving $11 \mathrm{~g}$ of $\mathrm{RRR}$ - $\alpha$-tocopherol acetate per day. A trans-10 shift of ruminal BH associated with milk fat depression due to oil supplementation of a high-wheat diet was observed, but vitamin E supplementation of dairy cows did not result in a

Received January 6, 2012.

Accepted April 29, 2012.

${ }^{1}$ Corresponding author: f.enjalbert@envt.fr reversal toward a trans-11 $\mathrm{BH}$ pathway, and did not restore milk fat content.

Key words: rumen biohydrogenation, trans-10 shift, milk fatty acid, vitamin $\mathrm{E}$

\section{INTRODUCTION}

Due to partial and incomplete ruminal biohydrogenation $(\mathbf{B H})$ of unsaturated FA, ruminant products, especially milk, contain $\mathrm{BH}$ intermediates, mainly trans FA including trans C18:1 and conjugated linoleic acids (CLA). A large number of positional and geometric isomers can be encountered. Among CLA, trans-10,cis-12 CLA has been shown to decrease the mammary synthesis of de novo FA and induces milk fat depression in dairy cows (Baumgard et al., 2000). Moreover, trans-10, cis-12 CLA has possible detrimental effects on human health (Ip et al., 2007). On the contrary, cis-9,trans-11 CLA is most desirable because of its anticarcinogenic and other health-promoting properties (Kritchevsky, 2000). Decreasing the trans-10/trans-11 ratio is, therefore, desirable. In most dietary conditions, trans-11 isomers are much more abundant than trans-10 isomers in milk fat. However, high-concentrate diets can result in a shift of $\mathrm{BH}$ from the trans-11 to trans-10 pathway, especially when based on corn silage or associated with an enrichment of the diet with an unsaturated FA source (Piperova et al., 2002; Loor et al., 2004; Nielsen et al., 2006). After addition of an unsaturated FA source, the isomeric profile progressively but strongly evolves, trans-10 C18:1 reaching a plateau after $10 \mathrm{~d}$, and trans-11 C18:1 reaching a peak after 6 $\mathrm{d}$ and then decreasing (Roy et al., 2006; Shingfield et al., 2006).

Because such a shift is not encountered with grassbased diets, Kay et al. (2005) hypothesized that vitamin E, which is abundant in pasture, could prevent it. However, as supplementing a TMR based on corn and grass silages with a large amount of synthetic vitamin E resulted in a trans-10 C18:1 proportion in milk fat 
Table 1. Ingredient and chemical composition of cow diets and in vitro incubation substrate

\begin{tabular}{lccc}
\hline & \multicolumn{2}{c}{ In vivo experiment } & \\
\cline { 2 - 3 } Composition & Control diet & Oil diet & $\begin{array}{c}\text { In vitro } \\
\text { substrate }\end{array}$ \\
\hline Ingredient, \% of DM & & & \\
Corn silage & 56.5 & 54.8 & 36.7 \\
Wheat & 22.2 & 21.5 & 44.1 \\
Soybean meal & 20.0 & 19.4 & 14.7 \\
Sunflower oil & 0.0 & 3.0 & 0.0 \\
Pure linoleic acid & 0.0 & 0.0 & 4.5 \\
Minerals and vitamins ${ }^{1}$ & 1.3 & 1.3 & 0.0 \\
Chemical composition, \% of DM & & & 15.5 \\
CP & 17.0 & 30.5 & 24.6 \\
NDF & 31.0 & 31.0 & 41.5 \\
Starch & 31.9 & 5.4 & 6.6 \\
Crude fat & 2.5 & & \\
\hline
\end{tabular}

${ }^{1}$ Contained $4 \% \mathrm{P}, 26 \% \mathrm{Ca}, 5 \% \mathrm{Mg}, 2 \% \mathrm{Na}, 5 \mathrm{~g}$ of $\mathrm{Zn} / \mathrm{kg}, 4 \mathrm{~g}$ of $\mathrm{Mn} / \mathrm{kg}, 1 \mathrm{~g}$ of Cu$/ \mathrm{kg}, 40 \mathrm{mg}$ of I $/ \mathrm{kg}, 20 \mathrm{mg}$ of

$\mathrm{Co} / \mathrm{kg}, 450,000 \mathrm{IU}$ of vitamin $\mathrm{A} / \mathrm{kg}, 100,000 \mathrm{IU}$ of vitamin $\mathrm{D} / \mathrm{kg}$, and $1,500 \mathrm{IU}$ of vitamin $\mathrm{E} / \mathrm{kg}$.

that was much over that encountered in pasture-fed cows, they concluded that vitamin $\mathrm{E}$ is not the primary reason explaining that trans-10 FA are not produced with grass diets. Pottier et al. (2006) partly succeeded in preventing the low milk fat syndrome due to trans-10 FA in cows receiving linseed-supplemented diets by adding supranutritional amounts of synthetic vitamin $\mathrm{E}$ to the diet, but when this vitamin addition started $3 \mathrm{wk}$ after beginning linseed supplementation, no effect could be observed, suggesting an interaction between vitamin $\mathrm{E}$ and disturbance over time of ruminal microbiota by fat. This 3 -wk interval is often considered as allowing a complete adaptation of the ruminal microbiota to a new diet, and the effects of vitamin $\mathrm{E}$ on the trans-10 shift sooner after oil addition (i.e., when the trans-10/ trans-11 ratio strongly evolves; Roy et al., 2006) have not been investigated.

Pottier et al. (2006) measured the effects of vitamin E after $21 \mathrm{~d}$ of supplementation, and discussed the changes due to vitamin $\mathrm{E}$ as probably resulting from effects on ruminal $\mathrm{BH}$, but did not directly study $\mathrm{BH}$. Moreover, they used synthetic vitamin E (DL- $\alpha$-tocopherol). The activity of synthetic vitamin $\mathrm{E}$ is known to be lower than that of natural vitamin E (RRR- $\alpha$-tocopherol) in animals (Dersjant-Li and Peisker, 2010), but the difference has not been studied in microbes, and lower activity could be overcome by a higher dose. As a consequence, the objectives of our study were, with a diet inducing a trans-10 shift, to investigate in vitro the differences of effects between natural and synthetic vitamins $\mathrm{E}$, and to investigate in vivo the effects of natural vitamin $\mathrm{E}$ supplementation beginning 1 wk after fat supplementation on ruminal and milk FA profiles.

\section{MATERIALS AND METHODS}

\section{In Vitro Experiment}

For the in vitro experiment, 2 ruminally fistulated lactating cows were used. They were adapted for $2 \mathrm{wk}$ to the control diet described in Table 1 . In vitro incubations were conducted during 3 consecutive weeks, and lasted $52 \mathrm{~h}$. One liter of rumen fluid was collected from each donor cow before the morning meal, and strained through a metal sieve (1.6-mm mesh). The rumen fluids were transported quickly (30 min) to the laboratory in anaerobic conditions at $39^{\circ} \mathrm{C}$. In the laboratory, the $\mathrm{pH}$ of the rumen fluids was measured and the 2 rumen fluids were mixed. The incubation substrate (Table 1) was based on the same ingredients as the cow diet, ground through a $0.5-\mathrm{mm}$ screen, and supplemented with pure linoleic acid (Sigma Co., St. Louis, MO).

Three series of incubations were performed during 3 successive weeks. On d 1 of each week, $40 \mathrm{~mL}$ of each rumen fluid and $40 \mathrm{~mL}$ of a bicarbonate buffer solution $\left(19.5 \mathrm{~g}\right.$ of $\mathrm{Na}_{2} \mathrm{HPO}_{4} \cdot 12 \mathrm{H}_{2} \mathrm{O} / \mathrm{L}, 9.24 \mathrm{~g}$ of $\mathrm{NaHCO}_{3} / \mathrm{L}, 0.705 \mathrm{~g}$ of $\mathrm{NaCl} / \mathrm{L}, 0.675 \mathrm{~g}$ of $\mathrm{KCl} / \mathrm{L}, 0.108$ $\mathrm{g}$ of $\mathrm{CaCl}_{2} \cdot 2 \mathrm{H}_{2} \mathrm{O} / \mathrm{L}$, and $0.180 \mathrm{~g}$ of $\mathrm{MgSO}_{4} \cdot 7 \mathrm{H}_{2} \mathrm{O} / \mathrm{L}$ ) were placed into six 250-mL flasks containing $1.20 \mathrm{~g}$ of substrate, including $60 \mathrm{mg}$ of pure linoleic acid. Two flasks were not supplemented with vitamin E, 2 flasks were supplemented with $30 \mathrm{mg}$ of a $37 \%$ RRR$\alpha$-tocopherol acetate oil solution (Artimon Sarl, Plérin, France), and 2 flasks were supplemented with $24 \mathrm{mg}$ of $50 \%$ DL- $\alpha$-tocopherol acetate (DSM Nutritional Products France SAS, Courbevoie, France). The buffer solution was prewarmed to $39^{\circ} \mathrm{C}$ and saturated with $\mathrm{CO}_{2}$. Its $\mathrm{pH}$ was then lowered to 6.0 with hydrochloric 
acid $(6 N)$ before being added to the $40 \mathrm{~mL}$ of rumen fluid. Next, the flasks were gassed with $\mathrm{CO}_{2}$ and closed with a rubber cap with a plastic tube immersed in water to vent fermentation gas without allowing oxygen entry. Incubations were carried out at $39^{\circ} \mathrm{C}$ in a water bath rotary shaker (Aquatron; Infors AG, Bottmingen, Switzerland). Flasks were stirred at $130 \mathrm{rpm}$ and kept out of the light during incubation. After 24 and $48 \mathrm{~h}$ of incubation, flasks were opened and $30 \mathrm{~mL}$ of buffer solution and the same substrate as at $\mathrm{d} 1$, including linoleic acid and vitamins, was added. Flasks were filled with $\mathrm{CO}_{2}$ before closing.

After $52 \mathrm{~h}$ of incubation, fermentations were stopped by placing the flasks into ice and the $\mathrm{pH}$ was measured. The contents of the flasks were immediately frozen at $-20^{\circ} \mathrm{C}$ and freeze dried (Virtis Freezemobile 25; Virtis Co. Inc., Gardiner, NY), weighed, ground, and homogenized in a ball mill (Dangoumau; Prolabo SA, Nogent-sur-Marne, France), and then stored at $-20^{\circ} \mathrm{C}$ until analysis.

\section{In Vivo Experiment}

For the in vivo experiment, 6 ruminally fistulated midlactation Holstein dairy cows were used in a $2 \times$ 2 crossover design. Cows were housed in individual stalls. Each period lasted $4 \mathrm{wk}$ and was divided into 2 subperiods: a 2 -wk washout subperiod, followed by a 2-wk oil diet subperiod, with the supplementation of vitamin $\mathrm{E}$ beginning at $\mathrm{d} 8$ of this oil diet subperiod. The washout was used to obtain a similar basal state of ruminal digestion before oil supplementation, allowing the study of FA profile kinetics without carryover effect of the diet used during the previous period.

During the washout subperiod, cows were allowed to consume 20-kg DM of a control diet based on corn silage (Table 1). During the 2 -wk oil diet subperiod, cows received the control diet supplemented with 600 $\mathrm{g}$ of sunflower oil. The ingredients of the control diet were mixed before distribution, and oil was poured on the mixed ration. From d 8 of the oil diet subperiod, cows received daily either no supplemental vitamin E or $30 \mathrm{~g}$ of a $37 \% \mathrm{RRR}$ - $\alpha$-tocopherol acetate oil solution (Artimon Sarl). This dose was similar to that used by Pottier et al. (2006) and, assuming a 100-L rumen volume, was in the same range as our in vitro dose. Diets and vitamin $\mathrm{E}$ supplement were distributed in 2 equal meals at 0900 and $1700 \mathrm{~h}$ and water was available ad libitum.

Milk yield was determined daily at each milking (0630 and $1730 \mathrm{~h}$ ). Ruminal and milk samples were taken at morning and evening milkings on d 1, 3, 5,
$7,9,11$, and 13 of the second subperiod. One liter of ruminal content was taken $5 \mathrm{~h}$ after the morning meal, strained through a metal sieve (1.6-mm mesh), and the $\mathrm{pH}$ was measured. Two 8-mL aliquots were transferred into $10-\mathrm{mL}$ vials containing $0.8 \mathrm{~mL}$ of $2 \% \mathrm{HgCl}_{2}$ and were stored at $-20^{\circ} \mathrm{C}$ until VFA analysis, and a $100-$ $\mathrm{mL}$ sample was kept at $-20^{\circ} \mathrm{C}$ for FA analysis. Milk samples were taken from morning and evening milking and were composited based on milk yield.

\section{Chemical Analysis}

Milk fat and true protein contents were determined by infrared analysis (MilkoScan 605; Foss Electric, Paris, France). The FA of milk and rumen in vivo and in vitro samples were analyzed as detailed by Zened et al. (2011). Briefly, FA were extracted and methylated using a procedure adapted from Park and Goins (1994). Thereafter, they were analyzed by GC (Agilent 6890N, equipped with a model 7683 autoinjector, Network GC System; Agilent Technologies Inc., Palo Alto, CA) using a fused silica capillary column $(100 \mathrm{~m} \times 0.25 \mathrm{~mm}$ i.d., $0.20-\mu \mathrm{m}$ film thickness; CPSil88; Varian Inc., Middelburg, the Netherlands). Two temperature programs were used. The first temperature program started at $60^{\circ} \mathrm{C}$ for $2 \mathrm{~min}$ and the temperature then was increased by $8^{\circ} \mathrm{C} / \mathrm{min}$ to $150^{\circ} \mathrm{C}$, held at $150^{\circ} \mathrm{C}$ for $12 \mathrm{~min}$, increased by $2^{\circ} \mathrm{C} / \mathrm{min}$ to $175^{\circ} \mathrm{C}$, held at $175^{\circ} \mathrm{C}$ for $20 \mathrm{~min}$, increased by $5^{\circ} \mathrm{C} /$ min to $225^{\circ} \mathrm{C}$, held at $225^{\circ} \mathrm{C}$ for $10 \mathrm{~min}$, and finally increased by $10^{\circ} \mathrm{C} / \mathrm{min}$ to $240^{\circ} \mathrm{C}$ and maintained at $240^{\circ} \mathrm{C}$ for $10 \mathrm{~min}$. The second temperature program, which improved the separation of trans-13+trans-14 $\mathrm{C} 18: 1$ from cis-9 $\mathrm{C} 18: 1$, started at $60^{\circ} \mathrm{C}$ for $3 \mathrm{~min}$ and the temperature was then increased by $8^{\circ} \mathrm{C} / \mathrm{min}$ to $190^{\circ} \mathrm{C}$, held at $190^{\circ} \mathrm{C}$ for $13 \mathrm{~min}$, increased by $5^{\circ} \mathrm{C} / \mathrm{min}$ to $225^{\circ} \mathrm{C}$, held at $225^{\circ} \mathrm{C}$ for $10 \mathrm{~min}$, increased by $10^{\circ} \mathrm{C} /$ min to a final temperature of $230^{\circ} \mathrm{C}$, and maintained at $230^{\circ} \mathrm{C}$ for $10 \mathrm{~min}$.

Concentrations of VFA in the rumen were determined by the method of Playne (1985) using automated gas separation, modified as follows: the ruminal samples were first centrifuged at $4,000 \times g$ for $20 \mathrm{~min}$ to separate the liquid phase. For protein removal, $1 \mathrm{~mL}$ of supernatant was mixed with $200 \mu \mathrm{L}$ of $25 \%$ metaphosphoric acid and further centrifuged at 20,000 $\times g$ for $15 \mathrm{~min}$. One milliliter of supernatant was added to $200 \mu \mathrm{L}(1 \%$ $\mathrm{vol} / \mathrm{vol}$ ) of 4-methylvaleric acid as internal standard and $1 \mu \mathrm{L}$ of the mixture was then injected into a gas chromatograph [model 5890 Series II, equipped with a flame ionization detector (FID); Hewlett-Packard Co., Avondale, PA]. 
Table 2. In vitro experiment: effects of natural or synthetic vitamin $\mathrm{E}$ on rumen FA profile ( $\%$ of total FA methyl esters)

\begin{tabular}{lccccc}
\hline & & \multicolumn{2}{c}{ Vitamin $\mathrm{E}$} \\
\cline { 2 - 3 } FA $^{1}$ & No vitamin & Natural & Synthetic & SEM & $P$-value \\
\cline { 2 - 4 } C14:0 & 0.58 & 0.60 & 0.61 & 0.01 & 0.051 \\
C16:0 & $7.35^{\mathrm{b}}$ & $7.62^{\mathrm{a}}$ & $7.58^{\mathrm{ab}}$ & 0.06 & 0.022 \\
C18:0 & 25.04 & 24.31 & 25.13 & 0.24 & 0.060 \\
$c 9$ C18:1 & $3.97^{\mathrm{b}}$ & $4.90^{\mathrm{a}}$ & $4.08^{\mathrm{b}}$ & 0.08 & $<0.001$ \\
$t 4$ to $t 8$ C18:1 & $0.58^{\mathrm{b}}$ & $0.75^{\mathrm{a}}$ & $0.63^{\mathrm{b}}$ & 0.02 & $<0.001$ \\
$t 9$ C18:1 & $0.25^{\mathrm{b}}$ & $0.33^{\mathrm{a}}$ & $0.25^{\mathrm{b}}$ & 0.01 & $<0.001$ \\
$t 10$ C18:1 & 13.02 & 14.36 & 13.31 & 0.36 & 0.052 \\
$t 11$ C18:1 & 1.23 & 1.21 & 1.36 & 0.05 & 0.13 \\
$t 12$ to $t 16$ C18:1 & $1.16^{\mathrm{b}}$ & $1.31^{\mathrm{a}}$ & $1.16^{\mathrm{b}}$ & 0.07 & 0.003 \\
$c 9, c 12$ C18:2 & $25.10^{\mathrm{a}}$ & $22.25^{\mathrm{b}}$ & $24.28^{\mathrm{a}}$ & 0.45 & 0.002 \\
$t 10, c 12$ CLA & $1.76^{\mathrm{c}}$ & $2.11^{\mathrm{b}}$ & $2.46^{\mathrm{a}}$ & 0.09 & $<0.001$ \\
$c 9, t 11$ CLA & $0.06^{\mathrm{b}}$ & $0.09^{\mathrm{ab}}$ & $0.16^{\mathrm{a}}$ & 0.02 & 0.023 \\
$c 9, c 12, c 15$ C18:3 & 0.65 & 0.65 & 0.68 & 0.01 & 0.14 \\
Total $t$ C18:1 & $16.24^{\mathrm{b}}$ & $17.96^{\mathrm{a}}$ & $16.72^{\mathrm{ab}}$ & 0.41 & 0.030 \\
Total CLA & $1.82^{\mathrm{c}}$ & $2.20^{\mathrm{b}}$ & $2.62^{\mathrm{a}}$ & 0.10 & $<0.001$ \\
Total $t 10$ FA & $14.78^{\mathrm{b}}$ & $16.46^{\mathrm{a}}$ & $15.78^{\mathrm{ab}}$ & 0.43 & 0.046 \\
Total $t 11$ FA & 1.29 & 1.30 & 1.52 & 0.07 & 0.047 \\
$t 10 / t 11$ ratio & $12.56^{\mathrm{b}}$ & $13.60^{\mathrm{a}}$ & $11.64^{\mathrm{c}}$ & 0.77 & 0.24 \\
\hline
\end{tabular}

${ }^{\mathrm{a}-\mathrm{c}}$ Means within a row with different superscripts differ $(P<0.05)$.

${ }^{1} c=$ cis; $t=$ trans.

\section{Calculations and Statistical Analysis}

Sums of CLA, trans C18:1, and trans-10 and trans-11 isomers were calculated by adding the assayed isomers. Data from the in vitro experiment were analyzed using the following model:

$$
\begin{gathered}
\text { Variable }=\text { mean }+ \text { series effect } \\
+ \text { treatment effect }+ \text { residual error },
\end{gathered}
$$

where treatment levels were no vitamin, natural vitamin E, and synthetic vitamin E. When the treatment effect was significant, a Tukey test was used for pairwise comparisons.

Data from the in vivo experiment collected from $\mathrm{d}$ 1 to $\mathrm{d} 7$ (i.e., before vitamin E supplementation) were analyzed using a repeated measures procedure with SYSTAT (version 9; SPSS Inc., Chicago, IL), determining linear, quadratic, and cubic effects of time and interaction of sampling day by vitamin $\mathrm{E}$ supplementation (time $\times$ vitamin $\mathrm{E}$ ). The model used was

$$
\begin{gathered}
\text { Variable }=\text { mean }+ \text { sampling day effect } \\
+ \text { cow effect }+ \text { residual error }
\end{gathered}
$$

Data from the in vivo experiment collected from $d 7$ to 13 (i.e., the last sampling day before the beginning of vitamin E supplementation and the samples follow- ing vitamin E supplementation) were analyzed using a repeated measures procedure with the following model:

$$
\begin{aligned}
\text { Variable } & =\text { mean }+ \text { sampling day effect }+ \text { cow effect } \\
& + \text { vitamin } \text { E effect }+ \text { residual error }
\end{aligned}
$$

Effects were declared significant at $P<0.05$.

\section{RESULTS}

\section{In Vitro Experiment}

Compared with the control, natural vitamin $\mathrm{E}$ increased the percentages of $\mathrm{C} 16: 0$, cis-9 C18:1, total trans $\mathrm{C} 18: 1$, and some minor individual trans $\mathrm{C} 18: 1$, total CLA, and trans-10,cis-12 CLA, but decreased the percentages of cis-9,cis-12 C18:2 (Table 2). Compared with the control, synthetic vitamin $\mathrm{E}$ increased both trans-10,cis-12 CLA and cis-9,trans-11 CLA. Compared with natural vitamin $\mathrm{E}$, synthetic vitamin $\mathrm{E}$ resulted in lower cis-9 C18:1 and higher cis-9,cis-12 C18:2 and CLA proportions.

\section{In Vivo Experiment}

During the first week of the oil diet subperiod, milk yield was not affected over time (Table 3 ), but milk fat content decreased from 33.4 to $25.0 \mathrm{~g} / \mathrm{kg}$. Milk protein content varied quadratically but within a narrow range. 


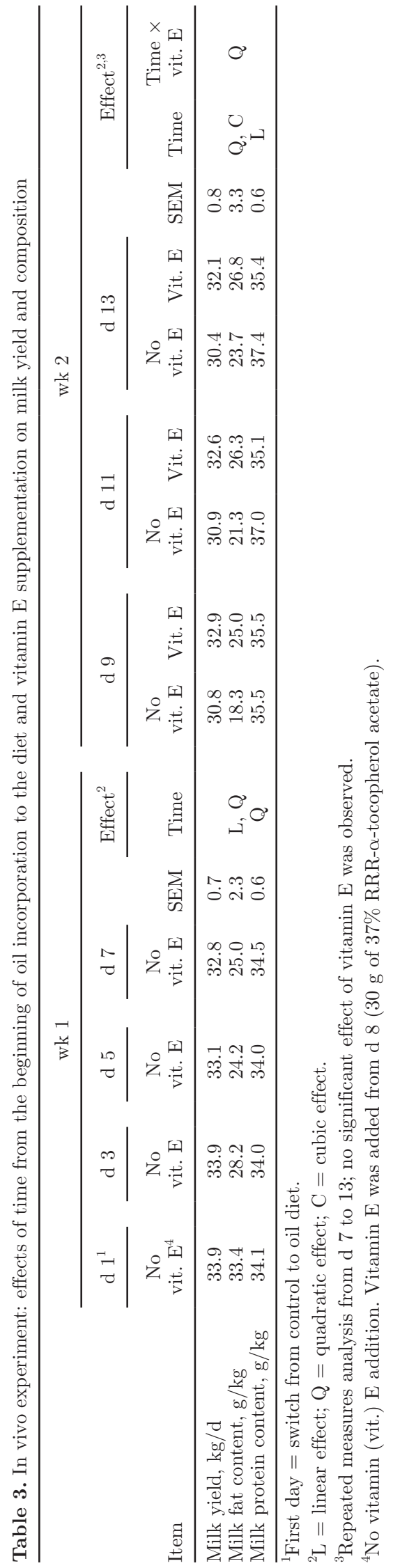

During the second week of the oil diet subperiod, milk yield was not affected by time and no time $\times$ vitamin E interaction was detected. Milk fat content increased with quadratic and cubic components, and a quadratic time $\times$ vitamin $\mathrm{E}$ interaction was linked to a decrease in milk fat content at $\mathrm{d} 9$ in cows that did not receive supplemental vitamin E. Milk protein content slightly increased over time and no time $\times$ vitamin $\mathrm{E}$ interaction was observed.

During wk 1 of the oil diet subperiod, the proportions of FA containing less than 18 carbons decreased in milk fat (Table 4). For C18 FA, the C18:0 proportion slightly increased and the proportion of cis-9, cis-12 C18:2, which is the main FA of sunflower oil, quadratically decreased over time, as did the proportion of total CLA, mainly due to a decrease in trans-10, cis-12 CLA. On the contrary, the proportion of total trans C18:1 FA increased over time, due to a more than 2-fold increase in trans-10 C18:1.

During wk 2 of the oil diet subperiod, time effects on FA with less than 18 carbons were much more limited: decreases in proportions were in a narrower range than during wk 1, and were not observed for C14:0 and C16:0. On the contrary, the proportion of this latter FA increased over time, but remained far lower than that observed at the beginning of the oil diet subperiod. Quadratic time $\times$ vitamin $\mathrm{E}$ interaction for even-chain saturated C4:0 to C12:0 FA reflected values that increased over time with vitamin E supplementation and were almost steady in the unsupplemented cows. The proportion of cis-9, cis-12 C18:2 was fairly constant with vitamin $\mathrm{E}$ addition and followed a quadratic pattern, with a maximal value at $\mathrm{d} 9$ in unsupplemented cows. Total CLA were not affected by time or time $\times$ vitamin $\mathrm{E}$ interaction, but the proportion of trans-10, cis-12 CLA was affected by a time $\times$ vitamin $E$ interaction, resulting in a $40 \%$ lower proportion in supplemented than in unsupplemented cows from d 9. Trans-10 C18:1 was also affected by a time $\times$ vitamin $\mathrm{E}$ interaction, but average values during the supplementation period were similar in supplemented and unsupplemented cows. During this second week, C18:0 proportion was not affected over time. The time $\times$ vitamin $\mathrm{E}$ interaction had a significant effect with a trend $(P=0.064)$ toward a quadratic effect.

In the rumen, $\mathrm{pH}$ and VFA concentrations were not affected by time during the 2 wk of oil supplementation, and were not affected by time $\times$ vitamin $E$ interaction (Table 5). The proportions of acetate and isovalerate decreased during wk 1 and increased during wk 2, independently of vitamin E supplementation, whereas the proportion of valerate followed an opposite pattern.

The ruminal proportions of FA with less than 18 carbons were only slightly affected by time (Table 6): even- 
Table 4. In vivo experiment: effects of time from the beginning of oil incorporation to the diet and vitamin E supplementation on milk FA profile (\% of total FA methyl esters)

\begin{tabular}{|c|c|c|c|c|c|c|c|c|c|c|c|c|c|c|c|}
\hline \multirow[b]{3}{*}{$\mathrm{FA}^{1}$} & \multicolumn{6}{|c|}{ wk 1} & \multicolumn{9}{|c|}{ wk 2} \\
\hline & \multirow{2}{*}{ 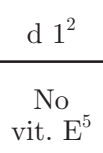 } & \multirow{2}{*}{$\begin{array}{c}\text { d } 3 \\
\text { No } \\
\text { vit. E }\end{array}$} & \multirow{2}{*}{$\begin{array}{c}\text { d } 5 \\
\text { No } \\
\text { vit. E }\end{array}$} & \multirow{2}{*}{$\begin{array}{c}\text { d } 7 \\
\text { No } \\
\text { vit. E }\end{array}$} & \multirow[b]{2}{*}{ SEM } & \multirow{2}{*}{$\begin{array}{l}\text { Effect }^{3} \\
\text { Time }\end{array}$} & \multicolumn{2}{|c|}{ d 9} & \multicolumn{2}{|c|}{ d 11} & \multicolumn{2}{|c|}{ d 13} & \multirow[b]{2}{*}{ SEM } & \multicolumn{2}{|c|}{ Effect $^{3,4}$} \\
\hline & & & & & & & $\begin{array}{c}\text { No } \\
\text { vit. E }\end{array}$ & Vit. E & $\begin{array}{c}\text { No } \\
\text { vit. E }\end{array}$ & Vit. E & $\begin{array}{c}\text { No } \\
\text { vit. E }\end{array}$ & Vit. E & & Time & $\begin{array}{c}\text { Time } \times \\
\text { vit. } \mathrm{E}\end{array}$ \\
\hline $\mathrm{C} 4: 0$ to $\mathrm{C} 12: 0$ even $\mathrm{FA}$ & 9.91 & 7.56 & 6.95 & 6.32 & 0.41 & $\mathrm{~L}, \mathrm{Q}$ & 5.08 & 5.66 & 4.68 & 6.03 & 4.80 & 6.12 & 0.32 & $\mathrm{Q}$ & \\
\hline C9 to $\mathrm{C} 17$ odd FA & 3.71 & 3.12 & 2.78 & 2.72 & 0.07 & L, Q & 2.70 & 2.61 & 2.61 & 2.62 & 2.54 & 2.75 & 0.06 & & \\
\hline C14:0 & 10.50 & 9.05 & 8.18 & 7.89 & 0.34 & $\mathrm{~L}, \mathrm{Q}$ & 7.24 & 7.78 & 7.48 & 7.78 & 7.23 & 8.07 & 0.22 & & \\
\hline C16:0 & 25.43 & 21.51 & 19.71 & 18.53 & 0.53 & $\mathrm{~L}, \mathrm{Q}, \mathrm{C}$ & 19.29 & 20.10 & 20.49 & 20.34 & 20.55 & 20.42 & 0.78 & $\mathrm{~L}$ & \\
\hline C18:0 & 6.67 & 8.04 & 8.48 & 8.28 & 0.50 & L, Q & 7.39 & 8.38 & 8.22 & 8.11 & 9.85 & 7.98 & 0.57 & & $\mathrm{G}$ \\
\hline$c 9 \mathrm{C} 18: 1^{5}$ & 16.70 & 18.23 & 18.82 & 17.83 & 0.52 & $\mathrm{~L}, \mathrm{Q}$ & 18.17 & 19.51 & 19.41 & 19.14 & 22.07 & 18.66 & 1.06 & G & $\mathrm{Q}$ \\
\hline$t 4$ to $t 8 C 18: 1^{5}$ & 0.60 & 0.69 & 0.68 & 0.65 & 0.06 & & 0.66 & 0.59 & 0.74 & 0.54 & 0.74 & 0.59 & 0.10 & & \\
\hline t9 C18:1 & 0.32 & 0.40 & 0.46 & 0.49 & 0.06 & & 0.38 & 0.48 & 0.43 & 0.34 & 0.40 & 0.40 & 0.09 & & \\
\hline$t 10 \mathrm{C} 18: 1$ & 9.50 & 14.99 & 17.22 & 20.58 & 0.69 & $\mathrm{~L}, \mathrm{C}$ & 20.61 & 17.88 & 17.98 & 17.74 & 14.77 & 17.92 & 1.17 & $\mathrm{~L}$ & $\mathrm{Q}, \mathrm{C}$ \\
\hline$t 11$ C18:1 & 2.43 & 2.25 & 2.13 & 1.96 & 0.25 & & 1.91 & 1.95 & 1.80 & 2.05 & 1.76 & 2.00 & 0.17 & & \\
\hline$t 12$ to $t 16 \mathrm{C} 18: 1$ & 1.13 & 1.22 & 1.14 & 1.22 & 0.08 & & 1.32 & 1.11 & 1.29 & 1.14 & 1.35 & 1.07 & 0.16 & & \\
\hline$c 9, c 12 \mathrm{C} 18: 2$ & 2.79 & 2.39 & 2.41 & 2.44 & 0.16 & $\mathrm{Q}$ & 2.80 & 2.54 & 2.57 & 2.42 & 2.32 & 2.32 & 0.09 & $\mathrm{Q}, \mathrm{C}$ & $\mathrm{Q}$ \\
\hline$t 10, c 12$ CLA & 0.26 & 0.09 & 0.07 & 0.07 & 0.03 & L, Q, C & 0.10 & 0.05 & 0.08 & 0.05 & 0.08 & 0.05 & 0.01 & & $\mathrm{Q}, \mathrm{C}$ \\
\hline$c 9, t 11$ CLA & 0.88 & 0.94 & 0.92 & 0.76 & 0.08 & & 0.89 & 0.88 & 0.87 & 0.82 & 0.82 & 0.80 & 0.05 & & \\
\hline$c 9, c 12, c 15$ C18:3 & 0.23 & 0.19 & 0.19 & 0.21 & 0.01 & $\mathrm{Q}$ & 0.23 & 0.22 & 0.22 & 0.20 & 0.19 & 0.19 & 0.01 & $\mathrm{Q}$ & \\
\hline Total $t C 18: 1$ & 13.98 & 19.55 & 21.59 & 24.89 & 0.88 & $\mathrm{~L}, \mathrm{C}$ & 24.88 & 22.01 & 22.23 & 21.79 & 19.02 & 21.98 & 1.34 & $\mathrm{~L}$ & Q, C \\
\hline Total CLA & 1.23 & 1.11 & 1.07 & 0.91 & 0.09 & $\mathrm{~L}$ & 1.08 & 1.01 & 1.04 & 0.95 & 0.97 & 0.93 & 0.06 & G & \\
\hline Total $t 10 \mathrm{FA}$ & 9.76 & 15.08 & 17.30 & 20.64 & 0.70 & $\mathrm{~L}, \mathrm{C}$ & 20.71 & 17.93 & 18.06 & 17.79 & 14.85 & 17.96 & 1.18 & $\mathrm{~L}$ & $\mathrm{Q}, \mathrm{C}$ \\
\hline Total $t 11 \mathrm{FA}$ & 3.40 & 3.27 & 3.13 & 2.80 & 0.31 & & 2.89 & 2.91 & 2.75 & 2.95 & 2.66 & 2.88 & 0.20 & & \\
\hline$t 10 / t 11$ ratio & 3.86 & 5.03 & 5.78 & 7.36 & 0.39 & $\mathrm{~L}$ & 7.41 & 6.63 & 6.58 & 5.91 & 5.41 & 5.96 & 0.31 & $\mathrm{~L}, \mathrm{Q}, \mathrm{C}$ & \\
\hline
\end{tabular}

${ }^{3} \mathrm{G}=$ global effect without significance of linear; quadratic and cubic effects; $\mathrm{L}=$ linear effect; $\mathrm{Q}=$ quadratic effect; $\mathrm{C}=$ cubic effect.

. ${ }^{4}$ Repeated measures analysis from d 7 to 13 ; the effect of vitamin $\mathrm{E}$ was significant only for the trans $10 /$ trans 11 ratio.

( ${ }^{5}$ No vitamin (vit.) E addition. Vitamin E was added from d 8 (30 g of $37 \%$ RRR- $\alpha$-tocopherol acetate). 


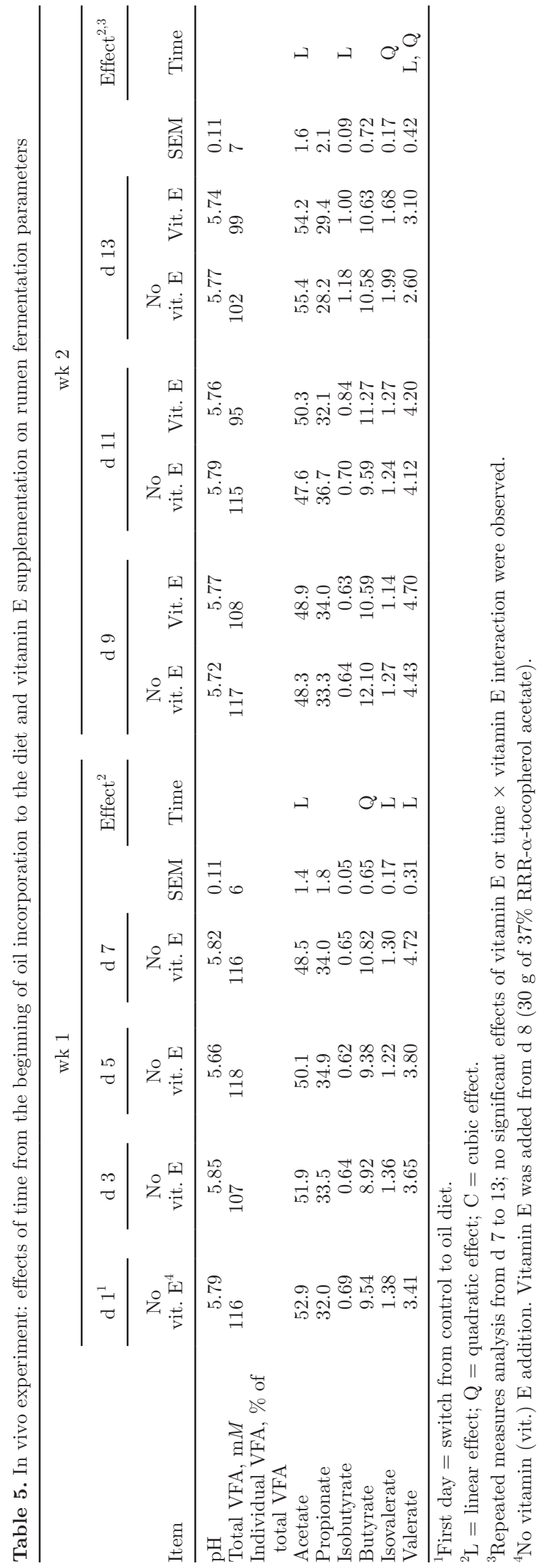

and odd-chain FA with less than 18 carbons decreased at the beginning of the first week and then remained stable. During the second week, C14:0 increased over time, and vitamin $\mathrm{E}$ supplementation resulted in an increase of odd-chain FA over time. The proportions of cis-9 C18:1, cis-9,cis-12 C18:2, and cis-9,cis-12,cis-15 C18:3 in the rumen content were not affected by time or time $\times$ vitamin interaction. Total CLA decreased during wk 2, but with high variability. Among CLA isomers, trans-10,cis-12 CLA remained fairly constant over time and did not depend on vitamin E supplementation, and cis-9,trans-11 CLA strongly increased from 0.14 to $0.51 \%$ of total FA during wk 1, and decreased to $0.03 \%$ during wk 2 , independently of vitamin $\mathrm{E}$ supplementation. Trans-10 C18:1 was the major trans isomer and increased during wk 1 and decreased during wk 2. A time $\times$ vitamin $\mathrm{E}$ interaction with a trend toward a linear effect $(P=0.057)$ was observed during wk 2, the proportions of trans-10 C18:1 being fairly constant in vitamin-supplemented cows, but decreasing in unsupplemented cows. The proportion of C18:0 also was stable at around $27 \%$ during wk 2 in vitamin-supplemented cows, but increased from 22 to $31 \%$ between d 9 and 13 in unsupplemented cows.

\section{DISCUSSION}

\section{Effects of Oil Addition}

Our dietary management resulted in a very rapid and important trans-10 shift, as ruminal proportions of trans-10,cis-12 CLA and trans-10 C18:1 were 2.2 and 5.8 times greater than those of cis-9,trans-11 CLA and trans-11 C18:1, respectively, as early as d 1 of the oil diet subperiod. The trans-10/trans-11 ratio reached around 10 in the rumen and 6 in milk from d 3. Our trans-10, cis 12-CLA proportions were very high compared with the literature data. In a recent meta-analysis, Glasser et al. (2008) reported that this isomer ranged from 0.0 to $6.6 \%$ of total duodenal $\mathrm{C} 18: 2$ in their data set, whereas it represented 6.1 to $12.5 \%$ of total ruminal C18:2 in our experiment. Our kinetics data of milk FA also contrast from those of Roy et al. (2006) who, using a $72 \%$ concentrate diet based on corn silage and adding sunflower oil, observed trans-10/ trans- 11 ratios around 0.6 before oil supplementation and during wk 1 of the oil diet subperiod, and around 5 after $10 \mathrm{~d}$ of oil feeding. The difference between studies could be due to the nature of concentrate: we used wheat, a highly fermentable starch, whereas Roy et al. (2006) used corn grain, a slowly fermentable starch. Accordingly, Jurjanz et al. (2004) observed higher milk trans-10 FA content when cows received wheat than when they received potatoes (another slowly ferment- 
Table 6. In vivo experiment: effects of time from the beginning of oil incorporation to the diet and vitamin E supplementation on rumen FA profile (\% of total FA methyl esters)

\begin{tabular}{|c|c|c|c|c|c|c|c|c|c|c|c|c|c|c|c|}
\hline \multirow[b]{3}{*}{$\mathrm{FA}^{1}$} & \multicolumn{6}{|c|}{ wk 1} & \multicolumn{9}{|c|}{ wk 2} \\
\hline & \multirow{2}{*}{ 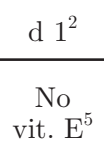 } & \multirow{2}{*}{ 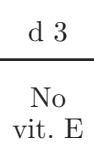 } & \multirow{2}{*}{$\begin{array}{c}\text { d } 5 \\
\text { No } \\
\text { vit. E }\end{array}$} & \multirow{2}{*}{$\begin{array}{c}\text { d } 7 \\
\begin{array}{c}\text { No } \\
\text { vit. E }\end{array}\end{array}$} & \multirow[b]{2}{*}{ SEM } & \multirow{2}{*}{$\begin{array}{c}\text { Effect }^{3} \\
\text { Time }\end{array}$} & \multicolumn{2}{|c|}{ d 9} & \multicolumn{2}{|c|}{ d 11} & \multicolumn{2}{|c|}{ d 13} & \multirow[b]{2}{*}{ SEM } & \multicolumn{2}{|c|}{ Effect $^{3,4}$} \\
\hline & & & & & & & $\begin{array}{l}\text { No } \\
\text { vit. } \mathrm{E}\end{array}$ & Vit. E & $\begin{array}{l}\text { No } \\
\text { vit. } E\end{array}$ & Vit. E & $\begin{array}{l}\text { No } \\
\text { vit. E }\end{array}$ & Vit. E & & Time & $\begin{array}{c}\text { Time } \times \\
\text { vit. } \mathrm{E}\end{array}$ \\
\hline C6:0 to $\mathrm{C} 12: 0$ even FA & 1.74 & 1.50 & 1.21 & 1.48 & 0.17 & $\mathrm{Q}, \mathrm{C}$ & 1.44 & 1.20 & 1.44 & 1.48 & 1.48 & 1.49 & 0.16 & & \\
\hline C7 to $\mathrm{C} 17$ odd FA & 1.65 & 1.41 & 1.34 & 1.47 & 0.08 & $\mathrm{Q}$ & 1.34 & 1.31 & 1.31 & 1.51 & 1.32 & 1.43 & 0.06 & & $\mathrm{~L}$ \\
\hline C14:0 & 0.86 & 0.91 & 0.88 & 0.87 & 0.06 & & 0.89 & 0.95 & 0.99 & 0.94 & 1.04 & 1.03 & 0.06 & $\mathrm{~L}$ & \\
\hline C16:0 & 8.74 & 8.15 & 8.33 & 8.21 & 0.24 & $\mathrm{C}$ & 8.32 & 8.34 & 8.28 & 8.33 & 8.29 & 8.38 & 0.30 & & \\
\hline $\mathrm{C} 18: 0$ & 22.59 & 26.47 & 25.45 & 24.01 & 2.45 & & 22.24 & 27.24 & 28.59 & 26.57 & 31.32 & 26.70 & 2.57 & & $\mathrm{~L}$ \\
\hline c9-C18:1 & 5.67 & 4.63 & 5.05 & 4.34 & 0.49 & G & 5.33 & 4.70 & 4.88 & 4.03 & 4.85 & 4.19 & 0.58 & & \\
\hline t4 to $t 8 C 18: 1$ & 1.10 & 0.82 & 0.79 & 0.71 & 0.13 & $\mathrm{~L}$ & 0.88 & 0.72 & 0.91 & 0.65 & 0.95 & 0.70 & 0.18 & & \\
\hline t9-C18:1 & 0.65 & 0.45 & 0.54 & 0.39 & 0.13 & $\mathrm{C}$ & 0.72 & 0.24 & 0.44 & 0.48 & 0.35 & 0.42 & 0.09 & & $\mathrm{Q}$ \\
\hline$t 10$ C18:1 & 23.37 & 23.43 & 27.23 & 27.16 & 2.18 & $\mathrm{~L}, \mathrm{C}$ & 29.03 & 25.05 & 23.31 & 24.29 & 21.79 & 24.04 & 2.75 & $\mathrm{~L}$ & G \\
\hline$t 11 \mathrm{C} 18: 1$ & 4.04 & 3.07 & 3.11 & 2.66 & 0.50 & & 2.79 & 2.83 & 2.44 & 2.65 & 2.11 & 2.81 & 0.45 & & \\
\hline$t 12$ to $t 16 C 18: 1$ & 1.74 & 1.52 & 1.80 & 1.41 & 0.21 & $\mathrm{C}$ & 1.58 & 1.40 & 1.70 & 1.30 & 1.60 & 1.28 & 0.23 & & \\
\hline$c 9, c 12$ C18:2 & 2.62 & 2.91 & 2.89 & 3.00 & 0.41 & & 3.97 & 3.48 & 3.09 & 2.94 & 3.11 & 3.69 & 0.79 & & \\
\hline$t 10, c 12$ CLA & 0.31 & 0.31 & 0.47 & 0.34 & 0.11 & & 0.29 & 0.26 & 0.34 & 0.26 & 0.27 & 0.28 & 0.10 & & \\
\hline$c 9, t 11$ CLA & 0.14 & 0.39 & 0.41 & 0.51 & 0.12 & $\mathrm{~L}$ & 0.10 & 0.52 & 0.01 & 0.03 & 0.02 & 0.04 & 0.17 & $\mathrm{~L}$ & \\
\hline$c 9, c 12, c 15$ C18:3 & 0.23 & 0.22 & 0.20 & 0.22 & 0.02 & & 0.21 & 0.20 & 0.22 & 0.23 & 0.18 & 0.22 & 0.02 & & \\
\hline Total $t$ C18:1 & 30.90 & 29.29 & 33.47 & 32.31 & 2.42 & $\mathrm{C}$ & 35.00 & 30.24 & 28.81 & 29.36 & 26.80 & 29.25 & 3.07 & $\mathrm{~L}$ & $\mathrm{~L}$ \\
\hline Total CLA & 0.55 & 0.84 & 1.02 & 0.98 & 0.21 & & 0.49 & 0.97 & 0.43 & 0.35 & 0.37 & 0.38 & 0.20 & $\mathrm{~L}$ & \\
\hline Total $t 10 \mathrm{FA}$ & 23.68 & 23.74 & 27.69 & 27.50 & 2.22 & $\mathrm{~L}, \mathrm{C}$ & 29.32 & 25.31 & 23.65 & 24.55 & 22.05 & 24.32 & 2.73 & $\mathrm{~L}$ & $\mathrm{~L}$ \\
\hline Total $t 11 \mathrm{FA}$ & 4.28 & 3.59 & 3.66 & 3.30 & 0.51 & & 2.99 & 3.54 & 2.53 & 2.73 & 2.22 & 2.91 & 0.57 & $\mathrm{~L}$ & \\
\hline$t 10 / t 11$ ratio & 8.18 & 8.68 & 9.16 & 11.10 & 1.26 & & 11.19 & 11.18 & 9.63 & 9.92 & 9.87 & 9.84 & 0.99 & $\mathrm{C}$ & \\
\hline
\end{tabular}

$\stackrel{\text { O }}{{ }^{3} \mathrm{G}}=$ global effect without significance of linear, quadratic, and cubic effects; $\mathrm{L}=$ linear effect; $\mathrm{Q}=$ quadratic effect; $\mathrm{C}=$ cubic effect.

${ }^{4}$ Repeated measures analysis from d 7 to 13; no significant effect of vitamin E was observed.

ऽ ${ }^{5}$ No vitamin (vit.) E addition. Vitamin E was added from d 8 (30 g of $37 \%$ RRR- $\alpha$-tocopherol acetate). 
able starch). Indeed, the quick ruminal degradation of wheat starch both leads to a large amount of starch degraded in the rumen and a big $\mathrm{pH}$ decrease after meals, compared with corn or potato starches. This can explain that corn or potatoes result in a lower trans-10/ trans-11 ratio than wheat, as both decreasing dietary starch (Kucuk et al., 2001) and adding ruminal buffers to the diet (Troegeler-Meynadier et al., 2007) decrease trans-10 FA in the rumen.

Milk fat content linearly and quadratically decreased during wk 1 of the oil diet subperiod, which is in line with present knowledge regarding the relationship between trans-10,cis-12 CLA and milk fat content (Baumgard et al., 2000). Nevertheless, in spite of high values of trans-10,cis-12 CLA in milk and rumen at d 1, milk fat content decrease was delayed. This is in agreement with the study of Perfield et al. (2004): using ruminal protected CLA, these authors observed a progressive decrease of milk fat content that became stable after $4 \mathrm{~d}$ of supplementation, but they published the FA composition of milk after 6 and $7 \mathrm{~d}$ of supplementation, preventing any kinetics approach of the relationship between milk trans-10,cis-12 CLA and milk fat content. In our experiment, at d 1, milk trans-10,cis-12 CLA exhibited a very high value compared with subsequent days, whereas rumen trans-10,cis-12 CLA was similar to values observed during the following days. This decrease in trans-10,cis-12 CLA in milk in spite of a constant ruminal proportion could suggest an evolution of the transfer of this FA from the digestive tract to milk fat. Consistent with our much lower proportion of trans-10,cis-12 CLA in milk fat than in the rumen from d 3, Chouinard et al. (1999) already demonstrated a low transfer of trans-10,cis-12 CLA from the digestive tract to milk, but their measures were performed after $5 \mathrm{~d}$ of abomasal infusion, which does not preclude a time evolution at the beginning of infusions. Such a decrease over time of trans-10,cis-12 CLA transfer from the digestive tract to milk could be explained by an effect of this isomer on milk transfer of FA with more than 16 carbons, as enzymes implicated in their mammary uptake are inhibited by trans-10,cis-12 CLA (Peterson et al., 2003). As for milk fat depression, reduction of FA uptake could have been delayed in the present study, underlying a time-dependent adaptation of mammary metabolism to a high ruminal production of trans-10, cis-12 CLA.

Beside this rapid change of trans FA, time effects were observed on other milk FA. The percentages of short- and medium-chain FA decreased during wk 1 of the oil diet subperiod, which is consistent with the literature relative to the effects of fat supplementation (Glasser et al., 2007). Some odd- and branched-chain VFA and FA in the rumen and milk fat also decreased during wk 1, which suggests modifications of microbial populations (Vlaeminck et al., 2006).

\section{Effects of Vitamin E Addition}

In vitro, both vitamin $\mathrm{E}$ forms increased the proportions of cis-9,trans-11 and trans-10,cis-12 CLA, synthetic vitamin E resulting in larger increases than the natural form, but in a higher proportion of cis-9, cis-12 C18:2 than the natural vitamin $\mathrm{E}$, which suggests that the differences in CLA percentages were not due to differences in isomerization efficiency. Similarly, the proportion of total trans-10 C18:1 was increased by natural vitamin $\mathrm{E}$, but, whereas statistically significant, the change was within a narrow range. Although not completely similar, the effects of natural and synthetic vitamin $\mathrm{E}$ were very limited, suggesting that vitamin $\mathrm{E}$ was neither a limiting factor for rumen $\mathrm{BH}$ nor a modulator of $\mathrm{BH}$ pathway.

Vitamin E supplementation did not affect fermentation parameters in vivo, which contrasts with the results of Naziroğlu et al. (2002), who observed in vitro that vitamin $\mathrm{E}$ addition increased the concentrations of acetate and propionate, but decreased that of butyrate. Hino et al. (1993) demonstrated that vitamin $\mathrm{E}$ addition partly alleviates the depression of growth and fibrolytic activity of rumen bacteria in incubates supplemented with safflower oil. Such an effect could be expected to affect rumen VFA production. In our experiment, we only measured rumen VFA concentrations. They were not clearly depressed by oil addition, which could explain the lack of effect of vitamin E.

As a whole, effects of vitamin E on FA profiles were limited. Vitamin E did not affect the rumen proportions of unsaturated dietary FA and most $\mathrm{BH}$ intermediates, which is consistent with the results of Chikunya et al. (2004), who demonstrated that vitamin E supplementation of the sheep diet did not affect the efficiency of rumen $\mathrm{BH}$ and the proportion of trans $\mathrm{C} 18: 1$ among FA. Some time $\times$ vitamin $\mathrm{E}$ interactions slightly affected FA profiles: during wk 2 of the oil diet subperiod in the in vivo experiment, vitamin $\mathrm{E}$ addition resulted in fairly steady percentages of rumen and milk C18:0, total trans $\mathrm{C} 18: 1$ and trans-10 C18:1, whereas without vitamin E supplementation, the C18:0 percentage increased and the trans C18:1 percentage decreased over time. These different patterns could suggest that vitamin $\mathrm{E}$ resulted in a more rapid adaptation of the reduction of trans C18:1 FA to C18:0 with a high-oil diet. The implication of vitamin $\mathrm{E}$ in the reduction of trans C18:1 to C18:0 has not been studied, contrary to the known implication of vitamin $\mathrm{E}$ in the reduction of CLA to trans C18:1 (Hughes et al., 1982). In this latter reaction, $\alpha$-tocopherolquinol acts as an electron donor 
during the reduction, but, as far as we are aware, no quantitative recommendation of vitamin E supply for cows related to this function has been proposed. In our study, vitamin E supplementation did not affect the ratio of trans $\mathrm{C} 18: 1$ to CLA, which could be due to the $300 \mathrm{mg}$ of vitamin E supplied by the standard commercial premix to all cows being sufficient to sustain this reduction. The more stable proportion of trans-10 C18:1 observed in milk fat in vitamin E-supplemented cows was due to a decrease in this proportion at $\mathrm{d} 9$ (i.e., $1 \mathrm{~d}$ after the beginning of vitamin E supplementation). However, the same decrease was observed in the rumen at $\mathrm{d} 7$ in cows that began to receive vitamin $\mathrm{E}$ at d 8 (results not shown), which makes a true relationship between vitamin E supplementation and this stabilization questionable.

The trans-10,cis-12 CLA proportion was lowered by vitamin $\mathrm{E}$ supplementation in milk fat, but not in rumen content. This suggests that vitamin E could have modified the transfer efficiency of trans10,cis 12 CLA isomer from the rumen to the mammary gland, which could create discrepancies between digestive and metabolic effects of vitamin E. Previous experiments regarding the effects of vitamin $\mathrm{E}$ on the trans-10 shift of BH only addressed FA composition of tissues or milk and milk fat content, and also showed limited effects of vitamin E supplementation. In steers receiving highgrain diets, Juárez et al. (2010) observed a reduction in the trans-10/trans-11 ratio in the backfat when steers fed a high-barley diet received supplemental vitamin E, but the same authors observed no effect of vitamin $\mathrm{E}$ on trans-10 C18:1 in intramuscular fat when steers received flax as a source of PUFA (Juárez et al., 2011). In dairy cows, vitamin E supplementation resulted in an increase in trans-10 FA (Bell et al., 2006) or no effect (Ferlay et al., 2010), but with a trans-10/trans-11 ratio that was far under 1, which strongly differs from our experimental conditions. In dairy cows, Pottier et al. (2006) observed a decrease in this ratio when vitamin E was supplemented from the beginning of linseed oil addition, but did not observe this effect when vitamin $\mathrm{E}$ was provided 3 wk after oil supplementation. Similarly, in our experiment, vitamin E was supplemented after the trans-10 shift, so our lack of effects is in line with the results of Pottier et al. (2006).

\section{CONCLUSIONS}

Vitamin E supplementation of dairy cows exhibiting a trans-10 shift of ruminal $\mathrm{BH}$ due to addition of oil supplementation to a high wheat diet did not result in a reversal of $\mathrm{BH}$ pathway toward trans-11 isomers production, which precluded any conclusion regarding differential effects of natural and synthetic vitamin E.

\section{ACKNOWLEDGMENTS}

The authors thank Y. Farizon, L. Reymond, and the staff at the experimental station (all of UMR 1289 Tandem, Castanet-Tolosan, France).

\section{REFERENCES}

Baumgard, L. H., B. A. Corl, D. A. Dwyer, A. Saebø, and D. E. Bauman. 2000. Identification of the conjugated linoleic acid isomer that inhibits milk fat synthesis. Am. J. Physiol. Regul. Integr. Comp. Physiol. 278:R179-R184.

Bell, J. A., J. M. Griinari, and J. J. Kennelly. 2006. Effect of safflower oil, flaxseed oil, monensin, and vitamin $\mathrm{E}$ on concentration of conjugated linoleic acid in bovine milk fat. J. Dairy Sci. 89:733-748.

Chikunya, S., G. Demirel, M. Enser, J. D. Wood, R. G. Wilkinson, and L. A. Sinclair. 2004. Biohydrogenation of dietary n-3 PUFA and stability of ingested vitamin $\mathrm{E}$ in the rumen, and their effects on microbial activity in sheep. Br. J. Nutr. 91:539-550.

Chouinard, P. Y., L. Corneau, D. M. Barbano, L. E. Metzger, and D. E. Bauman. 1999. Conjugated linoleic acids alter milk fatty acid composition and inhibit milk fat secretion in dairy cows. J. Nutr. 129:1579-1584.

Dersjant-Li, Y., and M. Peisker. 2010. Utilization of stereoisomers from alpha-tocopherol in livestock animals. J. Anim. Physiol. Anim. Nutr. (Berl.) 94:413-421.

Ferlay, A., B. Martin, S. Lerch, M. Gobert, P. Pradel, and Y. Chilliard. 2010. Effects of supplementation of maize silage diets with extruded linseed, vitamin $\mathrm{E}$ and plant extracts rich in polyphenols, and morning v. evening milking on milk fatty acid profiles in Holstein and Montbéliarde cows. Animal 4:627-640.

Glasser, F., M. Doreau, A. Ferlay, J. J. Loor, and Y. Chilliard. 2007. Milk fatty acids: Mammary synthesis could limit transfer from duodenum in cows. Eur. J. Lipid Sci. Technol. 109:817-827.

Glasser, F., P. Schmidely, D. Sauvant, and M. Doreau. 2008. Digestion of fatty acids in ruminants: A meta-analysis of flows and variation factors: 2. C18 fatty acids. Animal 2:691-704.

Hino, T., N. Andoh, and H. Ohgi. 1993. Effects of $\beta$-carotene and $\alpha$-tocopherol on rumen bacteria in the utilization of long-chain fatty acids and cellulose. J. Dairy Sci. 76:600-605.

Hughes, P. E., W. J. Hunter, and S. B. Tove. 1982. Biohydrogenation of unsaturated fatty acids. Purification and properties of cis-9,trans11-octadecadienoate reductase. J. Biol. Chem. 257:3643-3649.

Ip, M. M., S. O. McGee, P. A. Masso-Welch, C. Ip, X. Meng, L. Ou, and S. F. Shoemaker. 2007. The $t 10, c 12$ isomer of conjugated linoleic acid stimulates mammary tumorigenesis in transgenic mice over-expressing erbB2 in the mammary epithelium. Carcinogenesis 28:1269-1276

Juárez, M., M. E. R. Dugan, J. L. Aalhus, N. Aldai, J. A. Basarab, V. S. Baron, and T. A. McAllister. 2010. Dietary vitamin E inhibits the trans 10-18:1 shift in beef backfat. Can. J. Anim. Sci. 90:9-12.

Juárez, M., M. E. R. Dugan, J. L. Aalhus, N. Aldai, J. A. Basarab, V. S. Baron, and T. A. McAllister. 2011. Effects of vitamin E and flaxseed on rumen-derived fatty acid intermediates in beef intramuscular fat. Meat Sci. 88:434-440.

Jurjanz, S., V. Monteils, P. Juaneda, and F. Laurent. 2004. Variations of trans octadecenoic acid in milk fat induced by feeding different starch-based diets to cows. Lipids 39:19-24.

Kay, J. K., J. R. Roche, E. S. Kolver, N. A. Thomson, and L. H. Baumgard. 2005. A comparison between feeding systems (pasture and TMR) and the effect of vitamin E supplementation on plasma and milk fatty acid profiles in dairy cows. J. Dairy Res. 72:322-332.

Kritchevsky, D. 2000. Antimutagenic and some other effects of conjugated linoleic acid. Br. J. Nutr. 83:459-465.

Kucuk, O., B. W. Hess, P. A. Ludden, and D. C. Rule. 2001. Effect of forage:concentrate ratio on ruminal digestion and duodenal flow of fatty acids in ewes. J. Anim. Sci. 79:2233-2240.

Loor, J. J., K. Ueda, A. Ferlay, Y. Chilliard, and M. Doreau. 2004. Biohydrogenation, duodenal flow, and intestinal digestibility of 
trans-fatty acids and conjugated linoleic acids in response to dietary forage:concentrate ratio and linseed oil in dairy cows. J. Dairy Sci. 87:2472-2485.

Naziroğlu, M., T. Güler, and A. Yüce. 2002. Effect of vitamin E on ruminal fermentation in vitro. J. Vet. Med. A Physiol. Pathol. Clin. Med. 49:251-255.

Nielsen, T. S., E. M. Straarup, M. Vestergaard, and K. Sejrsen. 2006. Effect of silage type and concentrate level on conjugated linoleic acids, trans-C18:1 isomers and fat content in milk from dairy cows. Reprod. Nutr. Dev. 46:699-712.

Park, P. W., and R. E. Goins. 1994. In situ preparation of fatty acid methyl esters for analysis of fatty acid composition in foods. J. Food Sci. 59:1262-1266.

Perfield, J. W. II, A. L. Lock, A. M. Pfeiffer, and D. E. Bauman. 2004 Effects of amide-protected and lipid-encapsulated conjugated linoleic acid (CLA) supplements on milk fat synthesis. J. Dairy Sci. 87:3010-3016.

Peterson, D. G., E. A. Matitashvili, and D. E. Bauman. 2003. Diet-induced milk fat depression in dairy cows results in increased trans10,cis-12 CLA in milk fat and coordinate suppression of mRNA abundance for mammary enzymes involved in milk fat synthesis. J. Nutr. 133:3098-3102.

Piperova, L. S., L. Sampugna, B. B. Teter, K. F. Kalscheur, M. P. Yurawecz, Y. Ku, K. M. Morehouse, and R. A. Erdman. 2002. Duodenal and milk trans octadecenoic acid and conjugated linoleic acid (CLA) isomers indicate that postabsorptive synthesis is the predominant source of cis-9-containing CLA in lactating dairy cows. J. Nutr. 132:1235-1241.
Playne, M. J. 1985. Determination of ethanol, volatile fatty acids, lactic acid and succinic acid in fermentation liquids by gas chromatography. J. Sci. Food Agric. 36:638-644.

Pottier, J., M. Focant, C. Debier, G. De Buysser, C. Goffe, E. Mignolet, E. Froidmont, and Y. Larondelle. 2006. Effect of dietary vitamin $\mathrm{E}$ on rumen biohydrogenation pathways and milk fat depression in dairy cows fed high-fat diets. J. Dairy Sci. 89:685-692.

Roy, A., A. Ferlay, K. J. Shingfield, and Y. Chilliard. 2006. Examination of the persistency of milk fatty acid composition responses to plant oils in cows given different basal diets, with particular emphasis on trans-C18:1 fatty acids and isomers of conjugated linoleic acid. Anim. Sci. 82:479-492.

Shingfield, K. J., C. K. Reynolds, G. Hervás, J. M. Griinari, A. S. Grandison, and D. E. Beever. 2006. Examination of the persistency of milk fatty acid composition responses to fish oil and sunflower oil in the diet of dairy cows. J. Dairy Sci. 89:714-732.

Troegeler-Meynadier, A., M. C. Nicot, and F. Enjalbert. 2007. Effects of fat source and dietary sodium bicarbonate plus straw on the conjugated linoleic acid content of milk of dairy cows. Arch. Anim. Nutr. 61:406-415.

Vlaeminck, B., V. Fievez, A. R. J. Cabrita, A. J. M. Fonseca, and R J. Dewhurst. 2006. Factors affecting odd- and branched-chain fatty acids in milk: A review. Anim. Feed Sci. Technol. 131:389-417.

Zened, A., A. Troegeler-Meynadier, M. C. Nicot, S. Combes, Y. Farizon, and F. Enjalbert. 2011. Starch and oil in the donor cow diet and starch in substrate differently affect the in vitro ruminal biohydrogenation of linoleic and linolenic acids. J. Dairy Sci 94:5634-5645. 